Romanticism on the Net

An open access journal devoted to British Romantic literature

$R \cdot \int_{\text {Remanonisisonontereve }}$

\title{
The Collected Letters of Robert Southey: A Romantic Circles \\ Edition. General Editors: Lynda Pratt, Tim Fulford, and Ian \\ Packer
}

\section{Michael Gamer}

Numéro 68-69, spring-fall 2017

Robert Southey

URI : https://id.erudit.org/iderudit/1070627ar

DOI : https://doi.org/10.7202/1070627ar

Aller au sommaire du numéro

Éditeur(s)

Université de Montréal

ISSN

2563-2582 (numérique)

Découvrir la revue

Citer ce compte rendu

Gamer, M. (2017). Compte rendu de [The Collected Letters of Robert Southey: A Romantic Circles Edition. General Editors: Lynda Pratt, Tim Fulford, and Ian

Packer]. Romanticism on the Net, (68-69). https://doi.org/10.7202/1070627ar d'utilisation que vous pouvez consulter en ligne.

https://apropos.erudit.org/fr/usagers/politique-dutilisation/ 


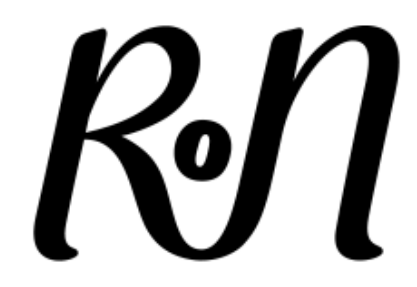

\section{Romanticism on the Net}

The Collected Letters of Robert Southey: A Romantic Circles Edition. General Editors: Lynda Pratt, Tim Fulford, and Ian Packer. Technical Editors: Laura Mandell and (for Part Six) David Rettenmaier. 2009- . Part One: 1791-1797, edited by Lynda Pratt, 2009; Part Two: 1798-1803, edited by Ian Packer and Lynda Pratt, 2011; Part Three: 1804-1809, edited by Carol Bolton and Tim Fulford, 2013; Part Four: 1810-1815, edited by Ian Packer and Lynda Pratt, 2013; Part Five: 1816-1818, edited by Ian Packer and Lynda Pratt, 2016; Part Six: 1819-1821, edited by Ian Packer and Lynda Pratt, 2017. http://www.rc.umd.edu/editions/southey letters.

Michael Gamer

University of Pennsylvania

\section{Biographical Note}

Michael Gamer is Professor of English at the University of Pennsylvania. His most recent book is Romanticism, Self-Canonization, and the Business of Poetry (Cambridge UP, 2017). 
Romanticism on the Net \#68-69 (Spring-Fall 2017). Special issue on Robert Southey. Guest-edited by Tim Fulford (De Montfort University) and Matthew Sangster (University of Glasgow)

1. Early in my years of graduate study, I had what might be called a "Robert Southey moment"-loosely defined as that instant when you become aware not only of your ignorance of Southey's writings but also that your disregard of him is willfully, even entirely, wrong. Having encountered Southey as an undergraduate only through Byron's withering Dedication to Don Juan, I met with a powerful counter-narrative in Marilyn Butler's "Repossessing the Past: The Case for an Open Literary History," a foundational essay in the Rethinking Historicism (1989) collection that also featured landmark articles by the likes of Marjorie Levinson, Paul Hamilton, and Jerome McGann. But it was Butler's piece that charmed me most, and that sent me to the stacks to read Joan of Arc, Thalaba, Kehama, and the 1797 and 1799 collections.

2. "Poets we have installed as canonical look more interesting individually, and far more understandable as groups," she declared, "when we restore some of their lost peers" (64). The Southey that emerged in Butler's manifesto was at once central to the age and key to understanding other writers. He appeared, moreover, in several guises: as surprising trendsetter, dogged adversary, and lasting influence. Here was a writer crucial to the Lyrical Ballads project and conspicuous in the longer poems of the Regency, the journalism of the post-Waterloo years, and the biographies and histories of the 1820s. Where my undergraduate years had introduced me to six major Romantic poets who seemed to have nothing to do with one another, each aloofly occupying his respective bit of Parnassus, figures like Southey — and later Bage, Barbauld, Edgeworth, Godwin, Lewis, Moore, Radcliffe, Robinson, Scott, Wollstonecraft, and countless others-promised a world of writers at once connected and contentious, a universe expanding. That sense of romanticism has only magnified for me in subsequent years.

3. A writer of broad acquaintance and omnivorous interests, Robert Southey produced a body of correspondence which dwarfs that of most other prominent writers both in quantity and range. Among eighteenth-century and romantic-period letter writers, Southey rivals Voltaire, Horace Walpole, and Catherine the Great in the size of his correspondence. As of 2009 , however, only thirty percent of his letters had been published, and these were spread over multiple editions at once out of print and hard to find. Beginning with the March 2009 release of Part One: 1791-1797, the Romantic Circles edition of The Collected Letters of 
Robert Southey has set out to redress this problem. In the intervening nine years, the editorial team of Lynda Pratt, Ian Packer, Tim Fulford, and Carol Bolton has published five more parts, making this by far the most ambitious Romantic Circles edition to date.

4. As Lynda Pratt mentioned in a private exchange, a project of this scale wouldn't be possible without the technical expertise of Laura Mandell, David Rettenmaier, and others at Romantic Circles. Especially valuable, she notes, is their help in "developing its searchability - e.g., you can click on in-text hyperlinks to key people in Southey's life and to information about the places he was linked to (the latter are keyed into a map); indices allow you to see letters listed by their addressee, and also by the person/s mentioned in them." While the project passed its halfway mark with the March 2017 publication of Part Six: 1819-1821, some 3,723 letters remain to be published. When completed, the edition will boast at least 7,500 letters from over 300 correspondents.

5. It's worth dwelling on the magnitude of this project. One might begin with the 200 archives the editors have scoured for manuscript letters, with the attendant processes of corresponding with librarians, transcribing manuscripts, and proofing all transcriptions. The editors have numbered each letter and provided bibliographic information on its archive, shelf number, watermark, addressee, stamp, and postmark. As is customary in the best scholarly editions, all letters are fully annotated. Even here, however, it is worth considering what full annotation means in the Internet Age with a writer as interdisciplinary as Southey. In surveying, for instance, W. S. Lewis's magisterial Yale edition of Horace Walpole's Correspondence, one finds on average eight or nine annotations per letter; the Collected Letters of Robert Southey is at once more exhaustive and more lush. A typical letter, such as the short one Southey wrote to John Murray II on 20 January 1816, features some thirteen annotations totaling nearly 900 words for a letter that itself is only 543 words long. Editorial glosses offer details on Vittorio Alfieri, the Spanish explorer "Ali Bey," Second Secretary of the Admiralty Sir John Barrow, Southey's Quarterly Review essays "On the Poor" and on the Lancaster-Bell education rivalry, John Martin's Account of the Natives of the Tonga Islands (1817), Jean Charles Léonard de Sismondi, Lord Elgin and the Elgin Marbles, Southey's review of Transactions of the London Missionary Society 
Romanticism on the Net \#68-69 (Spring-Fall 2017). Special issue on Robert Southey. Guest-edited by Tim Fulford (De Montfort University) and Matthew Sangster (University of Glasgow)

(1815), and an essay on Southey in A Biographical Dictionary of the Living Authors of Great Britain and Ireland (1816).

6. Given the range of topics broached in what is actually one of Southey's more "literary" letters, we can begin to understand why the edition has been used not just by literary scholars but also by historians of religion, politics, economics, and war. Where the correspondence of other Romantic writers - of William and Dorothy Wordsworth, for example-focuses primarily on family matters, Southey's letters routinely weigh in on the era's literary, political, and scholarly cultures. In many ways, the best comparison is Kathleen Coburn's edition of Coleridge's Notebooks, a project nearly fifty years in the making. For the four Southey editors, this edition will require nearly twenty.

7. Editions like this one live and die by their annotations, themselves testimonies to the knowledge and determination of the scholars who, through their glosses, thicken and make vivid an author's world. Among the gems contained in Part Six: 1819-1821 of the Collected Letters of Robert Southey is a gloss on one Anne Attersoll:

Daughter of Thomas Holmes (1751-1827), a wealthy East India merchant, who changed his name to Hunter on inheriting the Gobions estate in Hertfordshire in 1802 from his wife's grandfather. The same year, Ann Holmes eloped, aged sixteen, with Hugh Doherty, an impecunious thirty-year-old Irishman and officer in the Light Dragoons. Their marriage soon broke down, and Doherty published his account of events in The Discovery (1807). This revealed how, in an attempt to prevent the elopement, Ann had been confined by her parents in a "madhouse," from which he had helped her escape. After her separation from her husband, Ann Doherty (as she was then known) published a number of novels, including Ronaldsha (1808), The Castles of Wolfnorth and Mont Eagle (1812) and The Knight of the Glen (1815). Her personal life remained complex. In 1811 Hugh Doherty successfully sued the architect Philip William Wyatt (d. 1835 ) for 'criminal conversation' with his wife. Her relationship with Wyatt did not last and by 1818 she was referring to herself as Ann Attersoll, probably because she was living with John Attersoll (c. 1784-1822), a wealthy merchant, banker and MP for Wootton Bassett 1812-1813. At this time she corresponded 
with Southey, sending him a copy of her Peter the Cruel King of Castile and Leon: An Historical Play in Five Acts (1818). By 1820 (possibly earlier) she was living in France and had dropped the name of Attersoll and adopted that of Madame St Anne Holmes (much to Southey's confusion). A French translation of Roderick, the Last of the Goths, published in 1821 by Pierre Hippolyte Amillet de Sagrie (1785-1830), was dedicated to her. She remained in France and was later known by the surname de la Pigueliere.

Quoting Lynda Pratt again from our exchange about this massive undertaking, "All human life is there - don't get us started on the subject of Southey's rectal prolapse (expounded on in too much detail in letters to his doctor brother) ... [or] the rumours of John Wesley's inappropriate conduct towards a young female follower." Looking forward to its completion, the edition may very well achieve that rare state of being truly inexhaustible. 
Romanticism on the Net \#68-69 (Spring-Fall 2017). Special issue on Robert Southey. Guest-edited by Tim Fulford (De Montfort University) and Matthew Sangster (University of Glasgow)

\section{Works Cited}

Butler, Marilyn. "Repossessing the Past: The Case for an Open Literary History." Rethinking Historicism: Critical Readings in Romantic History, edited by Marjorie Levinson et al., Oxford: Blackwell, 1989, pp. 64-84.

Coburn, Kathleen, editor. Notebooks. By Samuel Taylor Coleridge. Pantheon / Routledge / Princeton UP, 1957-2002. 5 vols.

Lewis, W.S., editor. The Yale Edition of Horace Walpole's Correspondence. Yale UP, 1937-83. 48 vols. 